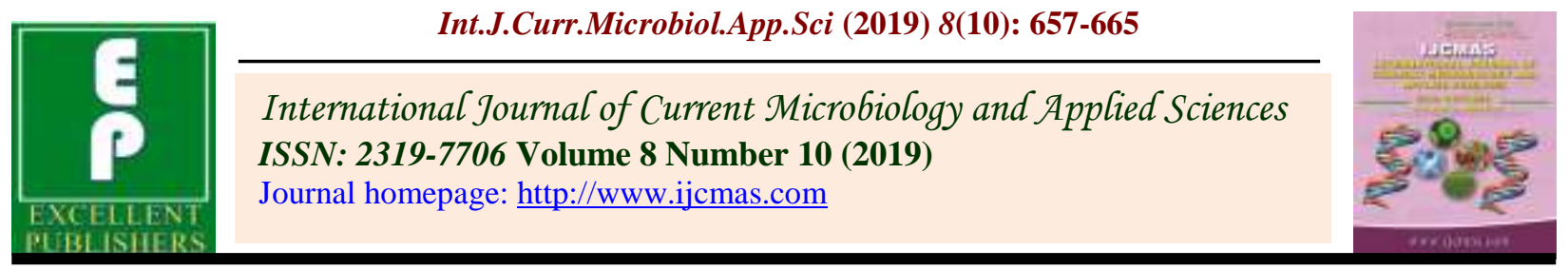

Original Research Article

https://doi.org/10.20546/ijcmas.2019.810.074

\title{
Evaluation of Plant Products as Surface Protectant of Packaging Materials against Corcyra cephalonica Staint. in Stored Pearlmillet Pennisetum glaucum (Linn.) R. Br. emend Stuntz
}

\author{
Anita Sharma*, K. C. Kumawat, S. K. Khinchi and Akhter Hussain \\ Department of Entomology, S K N College of Agriculture, Jobner-303329 (Rajasthan), India \\ Sri Karan Narendra Agriculture University, Jobner, Rajasthan, India
}

\begin{tabular}{|l|}
\hline K e y w o r d s \\
Plant oils, Gunny \\
bags, Pearlmillet, \\
Corcyra \\
cephalonica, \\
Impregnation
\end{tabular}

\section{A B S T R A C T}

The plant oils and extracts viz., Neem oil, mustard oil, castor oil and Neem seed kernel extract each at three concentrations (5.0, 7.5 and 10\%) and an insecticide check malathion $50 \mathrm{EC}(0.05$ and $0.1 \%)$ were evaluated by impregnating the gunny bags against Corcyra cephalonica Stainton (Lepidoptera: Galleriidae). The adult emergence, grain damage and weight loss were recorded after 270 days of storage pearlmillet, Pennisetum glaucum (Linn.). The adult emergence decrease with the increase in the concentration of test plant oils. Among the plant oils and extracts, the mean adult emergence (1.50 adults) was observed in NSKE followed by Neem oil (2.08 adults), mustard oil (2.84 adults) and castor oil (3.84 adults) 10.0 per cent dose. In NSKE and Neem oil, the adult emergence was decreased with increase in concentration. The mean per cent grain damage and weight loss also decreased with the increase in concentration of plant oils and extracts. Among the plant oils and extracts, the mean grain damage $(1.58 \%)$ and $(0.92 \%)$ were observed in Neem oil 10.0 per cent followed NSKE 10 per cent $(3.17 \%)$ and (1.50\%) respectively. With regards to malathion $50 \mathrm{EC}$, very low adult emergence, grain damage and weight loss were observed. All the plant oils and extracts found significantly superior over the untreated control. Among the plant oils and extracts the Neem oil and NSKE were the best treatments for impregnation of gunny bags having minimum adult emergence, grain damage and weight loss while mustard oil and castor oil were the least effective.

\section{Introduction}

Pearlmillet [Pennisetum glaucum (Linn.] R. Br. emend Stuntz. (Family: Gramineae) is one of the important millet crops, it comes next to sorghum in area and production. In India, it is grown in an area of 7.18 million hectares with an annual production of 9.53 million tonnes and average productivity of $1272 \mathrm{~kg} / \mathrm{ha}$.
(Anonymous, 2015-16). It is nutritionally better than many cereals as it is a good source of protein (12.6\%), fat (5\%) and minerals, as iron $(2.8 \%)$. Rajasthan is one of the chief pearlmillet growing states, occupying a total area of 4.97 million hectares under cultivation with an annual production of 4.94 million tonnes and average productivity of 1097 kg/ha. In Rajasthan, Barmer, Jodhpur, Nagaur, 
Jaipur, Churu, Sikar, Alwar, Jhunjhunu are major pearlmillet growing districts. Any loss of food grain in storage means less food is available for population. Therefore, the surplus food grain of nation needs keeping facilities and care during storage.

The grains in the storage are spoiled due to the infestation of organism such as insects, mites and rodents causing heavy losses. In India an overall post harvest losses during storage and handling have been estimated to the tune of 9.33\% (Agarwal, 1968). There are many species of insects and mites found infesting stored pearlmillet grains, but a few are major or primary pests.

Among the insects, the Angoumois grain moth, Sitotroga cerealella, Rhyzopertha dominica (Fab.) and rice moth, Corcyra cephalonica Staint. are important. The rice moth, Corcyra cephalonica Staint. (Lepidoptera: Galleriidae) heavily infests the stored pearlmillet and distributed in Asia, Africa, North America and Europe. Besides pearlmillet, it feeds on rice, maize, wheat, groundnut, gram, cotton seed, sorghum etc. The larvae cause damage to the grain by feeding under silken webs. When infestation is high the entire stock of grain may be converted into webbed mass. Ultimately, a characteristic foul odour is developed and qualitative loss is caused.

The success achieved so far in making the stored grains free from insect pests has been largely on sole reliance of pesticides. The indiscriminate use of fumigants and other toxic chemicals caused serious problems, like chronic and acute toxicity, development of insect resistance, pest resurgence, residue in food and hazards to human health and last but not least, the environmental pollution. The use of plant products assumed significance as an important component of insect pest management because of their economic viability and ecofriendly nature. They hold promise as an alternative to chemical insecticides to reduce pesticide load in the environment. Contrary to the chemical insecticides, they do not have mammalian toxicity and thus constitute no health hazards; surface persistence last for long time; have least adverse effect on seed germination, cooking quality and milling; less expensive and easily available. The increasing awareness of the hazards in use of chemical pesticides and several reported cases of food poisoning has created renewed interest in the use of plant products as grain protectants or as impregnation of packaging materials for managing the insect population in stored products. There are encouraging reports on the use of certain indigenous plant products as grain protectants (Chander et al., 2000, Sharma and Bhargava, 2001, Patel and Patel, 2002, Meena and Bhargava, 2003b and Jacob and Qamar, 2013). The insects cannot develop resistance against their own hormones, therefore, these are of great importance.

\section{Materials and Methods}

\section{Treatment of packaging material}

The gunny bags of $12 \times 18 \mathrm{~cm}^{2}$ was used for the purpose and sprayed with different concentrations of plant oils and plant extracts (Table 1) after filling up with sterilized and conditioned pearlmillet grains $(350 \mathrm{~g})$. The treatments were repeated at fortnightly interval.

The solutions of plant oils and extracts were made in water and that of oily nature plant oils in the acetone. A standard check (Malathion 50 EC@0.05) and an untreated check was maintained for comparison. The experiment was conducted in CRD and each treatment was replicated thrice. The sealed bags were kept with $C$. cephalonica infested stock to have natural infestation. 


\section{Method of recording observations}

Periodical inspection of the grains in bags was done to record natural infestation. The number of damaged grains and $F_{1}$ adult emergence was recorded by visual count. The adults were discarded every month after taking observations. The observations were recorded up to 270 days of storage. The grain weight loss was recorded by excluding the frass.

\section{Statistical analysis}

The per cent data on grain damage and weight loss were transformed into angular values (arc

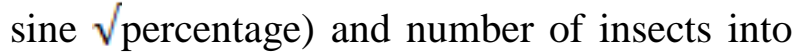
$\sqrt{ } \mathrm{X}+0.5$ values for analysis of variance.

\section{Results and Discussion}

Different plant oils, plant extracts and insecticide have been evaluated against $C$. cephalonica infesting stored pearl millet in the laboratory conditions. The plant oils and plant extract, viz., Neem oil, castor oil, mustard oil, NSKE (with 4 dose levels, i.e. 5.0, 7.5 and $10 \%$ ), and malathion (2 dose levels, i.e. 0.05 and $0.10 \%$ ) were evaluated. The gunny bags sprayed with different concentration of plant oils and plant extract after filling up with sterilized and conditioned pearlmillet grains (350 gm) and stored. These bags kept to have a natural infestation along with infested stock. The observations were recorded after 270 days of storage.

\section{Adult emergence}

Quite low or nil number of adults of $C$. cephalonica could emerge after 60 days of treatment of pearlmillet filled bags with plant products and insecticide, vis-a-vis, 6.33 adults in untreated. After 90 days, the minimum adult emergence was observed in NSKE 10.0 per cent which was found at par with Neem oil 10.0 per cent, while maximum adult emergence was recorded in castor oil 10.0 per cent (4.00 adult emergence), however, differed significantly over untreated control (30.67 adult emergence). The other treatments resulted in the middle order with regards to adult emergence (Table-2).

After 180 days of application of treatments, minimum adult emergence was recorded in the grains treated with NSKE 10.0 per cent (1.67 adults) which was found significantly superior over other treatments. This treatment was followed by Neem oil 10.0 and 7.5 per cent, and malathion 0.1 and 0.05 per cent. Contrary to this, high adult emergence was recorded in castor oil 5 per cent (9.33), this treatment was found significantly superior over untreated control (32.67 adults emergence). Adult emergence recorded in the other treatments ranked in the middle order.

After 270 days, all the treatments differed significantly over untreated control with regards to adult emergence. In the surface treatment with NSKE 10.0 per cent and Neem oil 10.0 per cent and malathion 0.05 and 0.1 per cent revealed minimum adult emergence (3.00-4.33) was recorded. High adult emergence was recorded in castor oil 5 per cent and 7.5 per cent, mustard oil 5 per cent and neem oil 5 per cent treated bags, these were found at par each other and differed significantly over untreated control (38.67 adults). The ascending pattern of adult emergence was evidenced as: NSKE, malathion, Neem oil, mustard oil and castor oil.

\section{Grain damage}

After 60 days of treatment, all the treatments revealed negligible grain damage but differed significantly over the untreated $(18.33 \%)$ as evident in table-3 and fig.1. After 120 days of storage of pearlmillet, the grain damage was minimum in the Neem oil 10.0 per cent $(1.33 \%)$ followed by NSKE 10.0 per cent (3.33\%), malathion 50 EC 0.05 and 0.10 per cent $(3.33 \%)$ and mustard oil 10.0 per cent 
$(4.33 \%)$. The castor oil 5 per cent treated packaging material showed maximum grain damage $(11.00 \%)$, this was significantly inferior to all the treatments but significantly superior over the untreated. As high as 26.33 per cent grain damage occurred in the untreated grain due to $C$. cephalonica.

The grain damage after 180 days of storage of pearlmillet was in the range of 2.33-18.67 per cent, the minimum being in the Neem oil 10.0 per cent and maximum in castor oil 5 per cent. The next effective treatments after Neem oil 10.0 per cent was NSKE 10.0 per cent (4.00\%) and malathion 0.1 per cent $(4.00 \%)$. As high as 43.28 per cent grain damage was recorded in the untreated which was significantly inferior to the other plant oils and extracts and insecticide treated packaging materials.

After 270 days of treatment, the grain damage was in the range of 2.67-25.33 per cent, the minimum in the Neem oil 10.0 per cent treated grain and maximum in the castor oil 5.0 per cent, the former was found significantly superior over rest of the treatments. This treatment was followed by malathion $50 \mathrm{EC}$ 0.1 per cent, NSKE 10.0 per cent and malathion 50 EC 0.05. The untreated control revealed a grain damage of as high as 64.00 per cent which was significantly inferior in revealing the grain damage over the treatments. The ascending pattern of grain damage was found to be in the order: Neem oil, malathion, NSKE, mustard oil and castor oil.

\section{Weight loss}

The quantitative loss observed after 60 days of storage in different grain samples treated with plant oils and extracts was found to be negligible and differed significantly over untreated $(9.00 \%)$. After 90 days of storage of pearlmillet, the quantitative loss was in the range of 0.67-5.67 per cent, the former being in the Neem oil 10.0 per cent and the latter in castor oil 10.0 per cent (Table-4, fig.-2). As high as 40.33 per cent weight loss occurred in untreated grain due to $C$. cephalonica damage. All the plant products and malathion 50 EC revealed low weight loss which differed significantly over untreated control.

After 180 days of storage, the minimum weight loss was observed in Neem oil 10.0 per cent $(1.33 \%)$ which differed significantly over rest of the treatments. This treatment was followed by malathion 50 EC 0.1 per cent (1.67\%), NSKE 10.0 per cent (2.00\%). Among these treatments, the castor oil 5.00 per cent revealed quite high weight loss $(8.67 \%)$ and significantly inferior over the other treatments. However, all the treatments were found significant in exhibiting the weight loss over untreated $(41.00 \%)$.

The weight loss was in the range of 1.67-11.67 per cent after 270 days of storage. It was minimum in the Neem oil 10.0 per cent $(1.67 \%)$. This treatment was followed by malathion 50 EC 0.1 per cent and NSKE 10 per cent. The castor oil 5.0 per cent was significantly inferior among the different treatments (11.67\% weight loss). However, all the treatments found significantly superior over the untreated ( $42.67 \%$ weight loss). The ascending pattern of weight loss was found to be in the order of: Neem oil, malathion 50 EC, NSKE, mustard oil and castor oil.

To manage the $C$. cephalonica, the technique of impregnation of packaging material with plant oils and plant extracts was chosen with the view to keep the grains free from toxic hazards. This method has been shown to confer good protection to the seeds by earlier workers. Meena and Bhargava (2003b) observed the efficacy of A. indica, P. glabra ( $P$. pinnata), $C$. inophyllum, Cymbopogon flexuosus, Lawsonia inermis, Cocos nucifera, Indian mustard, sesame, groundnut, soybean and sunflower extract and/or oils @ 0.1,0.5 
and $1 \mathrm{ml} / 100 \mathrm{~g}$ broken seeds in controlling $C$. cephalonica.

The fecundity, egg viability and longevity of both male and female $C$. cephalonica decreased with increasing concentrations of the extracts and the oils. During present investigations, the neem, castor, mustard oil and neem seed kernel extract in three concentrations (5.0, 7.5 and $10.0 \%$ ) and one chemical viz., malathion $(0.05,00.1 \%)$ were used in evaluating their efficacy by impregnating the gunny bags. The results obtained during the present investigations on the efficacy of impregnation of packaging materials with different test compounds have been discussed here.

The data recorded during the present investigations revealed that after 60 days no adult emergence was recorded when gunny bags were impregnated with plant oils and extracts. However, the infestation in these treatments was observed at 90, 180 and 270 days of treatment, the most effective treatment was NSKE 10 per cent (1.33 adults), malathion 0.1 per cent (1.33 adults), malathion 0.05 (1.67 adults) and Neem oil 10 per cent (2.33 adults). It is apparent from the data that all the tested plant oils and extracts were found to be significantly superior in reducing the adult emergence over untreated control (6.33 adults). The present findings are conformity with Meena and Bhargava (2009) who found that no adult emergence was recorded in impregnated gunny and cloth bags. They observed the minimum number of adults emerged in the treatment of neem extract.

The seed damage observed after 60 days of treatment in storage was nil in NSKE, castor oil, neem oil and mustard oil 7.5 and $10.0 \%$ treated bags. The efficacy of neem oil 10 per cent and NSKE oil 10 per cent revealed low grain damage (2.67 and $5.33 \%$, respectively) after 270 days of treatment. These treatments were found significantly superior over rest of the treatments except the malathion 50EC (as standard check). The rest of the treatments resulted in the efficacy of lower order but significantly superior over the untreated. Yadav and Bhargava (2002) observed that Neem extract at $1.0 \mathrm{ml} 100 \mathrm{~g}^{-1}$ seeds resulted in the longest total life cycle (57.8 days), highest reduction in adult emergence $(85.7 \%)$, lowest number of eggs laid per female, highest reduction in egg viability $(65.3 \%)$ and shortest longevity for males (3.3 days) and females (4.8 days). No adverse effect on the germination of sorghum seeds at any interval was noticed.

Meena (2002) reported that impregnation of gunny bags and cloth bags with different plant products proved effective and in reducing the grain damage and weight loss while working on $C$. cephalonica. The weight loss in Neem oil 10 per cent (0.00-1.67\%) and NSKE oil 10 per cent $(0.00-2.67 \%)$ were minimum which were significantly superior over the other treatments except malathion 50EC 0.1 per cent. These treatments were followed by malathion 50 EC, NSKE $7.5 \%$, Neem oil 7.5 $\%$ and castor oil 10 per cent (0.00-6.67\%). The other treatments differed significantly over the untreated. Meena and Bhargava (2009) tested the grain damage after 12 months in different treatments which ranged from 1.1 to $25.0 \%$ and 1.0 to $22.1 \%$ in gunny bags and cloth bags, respectively impregnated in the plant products with corroborated with the present findings. They also recorded minimum damage and weight loss in the treatment of Neem extract which is in full conformity with the present reults. A meagre work has been conducted so far on the efficacy of plant oils and extracts as impregnation of packaging material against stored grain pests. 
Table.1 Treatments of plant products as surface treatment of packaging material

\begin{tabular}{|c|c|c|c|}
\hline $\begin{array}{c}\text { S. } \\
\text { No. }\end{array}$ & Common name & Scientific name & Dosages (\%) \\
\hline $\mathbf{1 .}$ & $\begin{array}{c}\text { Neem seed kernel } \\
\text { extract }\end{array}$ & Azadirachta indica A. Juss & $5.0,7.5,10.0$ \\
\hline $\mathbf{2 .}$ & Neem oil & Azadirachta indica A. Juss & $5.0,7.5,10.0$ \\
\hline $\mathbf{3 .}$ & Castor oil & Ricinus communis & $5.0,7.5,10.0$ \\
\hline $\mathbf{4 .}$ & Mustard oil & Brassica juncia & $5.0,7.5,10.0$ \\
\hline $\mathbf{5 .}$ & Malathion & - & $0.05,0.1$ \\
\hline $\mathbf{6 .}$ & Untreated & - & - \\
\hline
\end{tabular}

Table.2 Adult $\left(\mathrm{F}_{1}\right)$ emergence in plant products treated pearlmillet grain after certain period of storage

\begin{tabular}{|c|c|c|c|c|c|c|c|}
\hline S.No. & Plant products & Dose (\%) & $24 \mathrm{Hrs}$ & 90 days & 180 days & 270 days & Mean \\
\hline \multirow[t]{6}{*}{1.} & NSKE & 5.0 & 0.67 & 3.33 & 4.33 & 5.67 & 3.50 \\
\hline & & & 1.08 & 1.96 & 2.20 & 2.48 & \\
\hline & & 7.5 & 0.00 & 2.67 & 3.00 & 4.33 & 2.50 \\
\hline & & & 0.71 & 1.78 & 1.87 & 2.20 & \\
\hline & & 10.0 & 0.00 & 1.33 & 1.67 & 3.00 & 1.50 \\
\hline & & & 0.71 & 1.35 & 1.47 & 1.87 & \\
\hline \multirow[t]{6}{*}{2.} & castor oil & 5.0 & 1.00 & 7.67 & 9.33 & 9.67 & 6.92 \\
\hline & & & 1.22 & 2.86 & 3.14 & 3.19 & \\
\hline & & 7.5 & 0.00 & 6.33 & 7.67 & 8.33 & 5.58 \\
\hline & & & 0.71 & 2.61 & 2.86 & 2.97 & \\
\hline & & 10.0 & 0.00 & 4.00 & 5.67 & 5.67 & 3.84 \\
\hline & & & 0.71 & 2.12 & 2.48 & 2.48 & \\
\hline \multirow[t]{6}{*}{3.} & neem oil & 5.0 & 1.33 & 3.67 & 4.67 & 6.33 & 4.00 \\
\hline & & & 1.35 & 2.04 & 2.27 & 2.61 & \\
\hline & & 7.5 & 0.00 & 3.00 & 3.33 & 4.67 & 2.75 \\
\hline & & & 0.71 & 1.87 & 1.96 & 2.27 & \\
\hline & & 10.0 & 0.00 & 2.33 & 2.67 & 4.00 & 2.25 \\
\hline & & & 0.71 & 1.68 & 1.78 & 2.12 & \\
\hline \multirow[t]{6}{*}{4.} & Mustard oil & 5.0 & 1.10 & 4.67 & 5.67 & 6.67 & 4.53 \\
\hline & & & 1.26 & 2.27 & 2.48 & 2.68 & \\
\hline & & 7.5 & 0.00 & 3.33 & 4.00 & 5.33 & 3.17 \\
\hline & & & 0.71 & 1.96 & 2.12 & 2.41 & \\
\hline & & 10.0 & 0.00 & 2.67 & 3.67 & 5.00 & 2.84 \\
\hline & & & 0.71 & 1.78 & 2.04 & 2.35 & \\
\hline \multirow[t]{4}{*}{5.} & Malathion & 0.05 & 0.33 & 1.33 & 2.67 & 2.33 & 1.67 \\
\hline & & & 0.91 & 1.35 & 1.78 & 1.68 & \\
\hline & & 0.10 & 0.67 & 0.67 & 1.33 & 1.67 & 1.09 \\
\hline & & & 1.08 & 1.08 & 1.35 & 1.47 & \\
\hline & & & & & & & \\
\hline \multirow[t]{4}{*}{6.} & Untreated & - & 6.33 & 30.67 & 32.67 & 38.67 & 27.09 \\
\hline & & & 2.61 & 5.58 & 5.76 & 6.26 & \\
\hline & S.Em. \pm & - & 0.02 & 0.02 & 0.03 & 0.04 & - \\
\hline & $\mathrm{CD}(\mathrm{p}=0.05)$ & - & 0.05 & 0.07 & 0.09 & 0.11 & - \\
\hline
\end{tabular}

Figures in the parentheses are $\sqrt{\mathrm{X}+0.5}$ values 
Table.3 Grain damage (\%) due to rice moth in plant products treated pearlmillet after certain period of storage

\begin{tabular}{|c|c|c|c|c|c|c|c|}
\hline S.No. & Plant products & Dose (\%) & $\begin{array}{c}\text { 24Hrs } \\
\text { days }\end{array}$ & 90 days & 180 days & 270 days & Mean \\
\hline \multirow[t]{6}{*}{1.} & NSKE & 5.0 & 1.67 & 6.00 & 8.67 & 10.00 & 6.59 \\
\hline & & & 1.47 & 2.55 & 3.03 & 3.24 & \\
\hline & & 7.5 & 0.00 & 4.67 & 8.33 & 8.67 & 5.42 \\
\hline & & & 0.71 & 2.27 & 2.97 & 3.03 & \\
\hline & & 10.0 & 0.00 & 3.33 & 4.00 & 5.33 & 3.17 \\
\hline & & & 0.71 & 1.96 & 2.12 & 2.41 & \\
\hline \multirow[t]{6}{*}{2.} & Castor oil & 5.0 & 3.67 & 10.33 & 18.67 & 25.33 & 14.50 \\
\hline & & & 2.04 & 3.29 & 4.38 & 5.08 & \\
\hline & & 7.5 & 0.00 & 11.00 & 17.33 & 16.33 & 11.17 \\
\hline & & & 0.71 & 3.39 & 4.22 & 4.10 & \\
\hline & & 10.0 & 0.00 & 8.67 & 11.00 & 13.00 & 8.17 \\
\hline & & & 0.71 & 3.03 & 3.39 & 3.67 & \\
\hline \multirow[t]{6}{*}{3.} & Neem oil & 5.0 & 3.00 & 7.67 & 9.67 & 12.33 & 8.17 \\
\hline & & & 1.87 & 2.86 & 3.19 & 3.58 & \\
\hline & & 7.5 & 0.00 & 6.33 & 9.00 & 9.00 & 6.08 \\
\hline & & & 0.71 & 2.61 & 3.08 & 3.08 & \\
\hline & & 10.0 & 0.00 & 4.00 & 5.67 & 7.67 & 4.34 \\
\hline & & & 0.71 & 2.12 & 2.48 & 2.86 & \\
\hline \multirow[t]{6}{*}{4.} & Mustard oil & 5.0 & 3.33 & 8.67 & 10.33 & 14.67 & 9.25 \\
\hline & & & 1.96 & 3.03 & 3.29 & 3.89 & \\
\hline & & 7.5 & 0.00 & 7.00 & 9.67 & 10.33 & 6.75 \\
\hline & & & 0.71 & 2.74 & 3.19 & 3.29 & \\
\hline & & 10.0 & 0.00 & 4.33 & 8.33 & 10.00 & 5.67 \\
\hline & & & 0.71 & 2.20 & 2.97 & 3.24 & \\
\hline \multirow[t]{6}{*}{5.} & Malathion & 0.05 & 0.67 & 3.33 & 5.33 & 4.67 & 3.50 \\
\hline & & & 1.08 & 1.96 & 2.41 & 2.27 & \\
\hline & & 0.10 & 0.33 & 1.33 & 2.33 & 2.67 & 1.67 \\
\hline & & & 0.91 & 1.35 & 1.68 & 1.78 & \\
\hline & & 0.00 & 0.00 & 0.00 & 0.00 & 0.00 & 0.00 \\
\hline & & & 0.71 & 0.71 & 0.71 & 0.71 & \\
\hline \multirow[t]{4}{*}{6.} & Untreated & - & 18.33 & 86.33 & 87.00 & 84.00 & 68.92 \\
\hline & & & 4.34 & 9.32 & 9.35 & 9.19 & \\
\hline & S.Em. \pm & - & 0.04 & 0.02 & 0.03 & 0.05 & \\
\hline & $\mathrm{CD}(\mathrm{p}=0.05)$ & - & 0.12 & 0.07 & 0.10 & 0.14 & - \\
\hline
\end{tabular}

Figures in the parentheses are $\sqrt{\mathrm{X}+0.5}$ values 
Table.4 Weight loss (\%) due to rice moth in plant products treated pearlmillet grain after certain period of storage

\begin{tabular}{|c|c|c|c|c|c|c|c|}
\hline S.No. & Plant products & Dose $(\%)$ & 24 Hrs days & 90 days & 180 days & 270 days & Mean \\
\hline \multirow[t]{6}{*}{1.} & NSKE & 5.0 & 0.67 & 2.67 & 3.33 & 5.67 & 3.09 \\
\hline & & & 4.70 & 9.40 & 10.51 & 13.78 & \\
\hline & & 7.5 & 0.00 & 2.00 & 3.00 & 4.00 & 2.25 \\
\hline & & & 0.00 & 8.13 & 9.97 & 11.54 & \\
\hline & & 10.0 & 0.00 & 1.33 & 2.00 & 2.67 & 1.50 \\
\hline & & & 0.00 & 6.62 & 8.13 & 9.40 & \\
\hline \multirow[t]{6}{*}{2.} & Neem oil & 5.0 & 1.00 & 4.00 & 4.67 & 6.33 & 4.00 \\
\hline & & & 5.74 & 11.54 & 12.48 & 14.57 & \\
\hline & & 7.5 & 0.00 & 3.00 & 4.00 & 4.67 & 2.92 \\
\hline & & & 0.00 & 9.97 & 11.54 & 12.48 & \\
\hline & & 10.0 & 0.00 & 1.67 & 2.33 & 3.33 & 1.83 \\
\hline & & & 0.00 & 7.43 & 8.78 & 10.51 & \\
\hline \multirow[t]{6}{*}{3.} & Castor oil & 5.0 & 1.67 & 5.67 & 8.67 & 11.67 & 6.92 \\
\hline & & & 7.43 & 13.78 & 17.12 & 19.98 & \\
\hline & & 7.5 & 0.00 & 4.00 & 8.00 & 7.67 & 4.92 \\
\hline & & & 0.00 & 11.54 & 16.43 & 16.08 & \\
\hline & & 10.0 & 0.00 & 4.33 & 5.00 & 6.67 & 4.00 \\
\hline & & & 0.00 & 12.01 & 12.92 & 14.97 & \\
\hline \multirow[t]{6}{*}{4.} & Mustard oil & 5.0 & 1.33 & 4.00 & 5.00 & 7.67 & 4.50 \\
\hline & & & 6.62 & 11.54 & 12.92 & 16.08 & \\
\hline & & 7.5 & 0.00 & 3.67 & 4.67 & 5.33 & 3.42 \\
\hline & & & 0.00 & 11.04 & 12.48 & 13.35 & \\
\hline & & 10.0 & 0.00 & 2.67 & 3.33 & 4.67 & 2.67 \\
\hline & & & 0.00 & 9.40 & 10.51 & 12.48 & \\
\hline \multirow[t]{4}{*}{5.} & Malathion & 0.05 & 0.00 & 1.00 & 1.67 & 2.33 & 1.25 \\
\hline & & & 0.00 & 5.74 & 7.43 & 8.78 & \\
\hline & & 0.10 & 0.00 & 0.00 & 0.67 & 1.00 & 0.42 \\
\hline & & & 0.00 & 0.00 & 4.70 & 5.74 & \\
\hline \multirow[t]{4}{*}{6.} & Untreated & - & 9.00 & 40.33 & 42.67 & 41.00 & 33.25 \\
\hline & & & 17.46 & 39.42 & 40.79 & 39.82 & \\
\hline & S.Em. \pm & - & 0.04 & 0.02 & 0.02 & 0.02 & \\
\hline & $\mathrm{CD}(\mathrm{p}=0.05)$ & - & 0.11 & 0.05 & 0.04 & 0.07 & - \\
\hline
\end{tabular}

Figures in the parentheses are arc sine $\sqrt{\text { percentage }}$ values

A commendable work was done by Chander et al. (2000), Sharma and Bhargava (2001), Patel and Patel (2002), Yadav and Bhargava (2002), Shukla et al. (2002), Dwivedi and Garg (2003), Jadhav and Ghule (2003), Meena and Bhargava (2003b), Jacb and Qamar (2013) and Said and Pashte (2015).
The plant oils and extracts, viz., NSKE, neem oil, mustard oil and castor oil were evaluated against rice moth, $C$. cephalonica as surface treatment of packaging material (gunny bags). The NSKE 10.0 per cent and neem oil 10.0 per cent were most effective. These treatments were followed by mustard oil and castor oil 10 . 


\section{References}

Agarwal, N.S. 1968. Editical, Bulletin of Grain Technology, 4: 1.

Ansari, K.K., Prakash, S. and Pandey, P.N. 2003. Effect of some indigenous plant products on the loss of weight in Jowar infested with Corcyra cephalonica Staint. Flora and Fauna- Jhansi, 9(2): 75-76.

Chander, Harish, Ahuja, D.K., Nagender, A. and Berry, S.K. 2000. Repellency of different plant extracts and commercial formulations used as prophylactic sprays to protects bagged grain against Tribolium castaneum - a field study. Journal of Food Science and Technology, 37(6): 582-585.

Choudhary, S.O. and Mahla, J.C. 2001. Insect infecting stored wheat in different climatic regions of Haryana. Crop Research, 21(3): 384-386.

Dwivedi, S.C. and Seema, Garg 2003. Toxicity evaluation of flower extract of Lantana camara on the life cycle of Corcyra cephalonica. Indian Journal of Entomology, 65(3): 330-334.

Jacob, P. and Qamar A. 2013. Reproductive impairment and lethal effects of selected combinations of some essential oils against the rice moth, Corcyra cephalonica. European Journal of Experimental Biology, 3(3): 409-415.

Jadhav, S. and Ghule, R.N. 2003. Qualitative changes in total body proteins and heamolymph proteins due to azadirachin in the larva of Corcyra cephalonica (Staint.). Entomon, 28(2): 157-159.

Meena, B.L. and Bhargava, M.C. 2003. Effect of plant products on reproductive potential of Corcyra cephalonica Staint. Annals of Plant Protection Science, 11(2): 196-200.

Meena, B.L. and Bhargava, M.C. 2009. Impregnation of packing materials on infestation of Corcyra cephalonica Stainton in groundnut. Annals of Plant Protection Sciences, 17(1): 99-102.

Meena, H.R., Rana, B.S., Ameta, O.P., Meena, B.M., Kumar, A. and Meena, A. 2014. Estimation of losses in stored maize caused by Corcyra cephalonica Stainton in Southern Rajasthan and their ecofriendly management. Journal of Biopest 7(2): 186-194.

Patel, R.A. and Patel, B.R. 2002. Evaluation of certain plant products as grain protectants against the rice moth, Corcyra cephalonica Staint in stored rice. Pest Management and Economic Zoology, 10(2): 121-124.

Said, P.P. and Pashte, V.V. 2015. Botanicals: The protectants of stored grain pests. Trends in Biosciences, 8(15): 72-74.

Sharma, K.C. and Bhargava, M.C. 2001. Ovicidal effect of some growth disruptions compounds on rice moth, Corcyra cephalonica Staint. Indian Journal of Applied Entomology, 15: 24-28.

Shukla, A.C., Shahi, S.K. and Aunpam Dikshit, 2002. Eucalyptus pauciflora -a potential source of sustainable, ecofriendly storage pesticide, Biotechnology of microbes and sustainable utilization (Edited by Rajak, R. C.), Published by Scientific Publishers, Jodhpur (India), pp. 93-107.

Veeranki, S. and Reddy, K.D. 2004. Evaluation of various products as grain protectants against rice moth (Corcyra cephalonica). Journal of Research ANGRAU, 32(4): 2933.

Yadav, J.P. and Bhargava, M.C. 2002. Effect of certain botanical products on biology of Corcyra cephalonica Stainton. Indian Journal of Plant Protection 30(2): 207209.

\section{How to cite this article:}

Anita Sharma, K. C. Kumawat, S. K. Khinchi and Akhter Hussain 2019. Evaluation of Plant Products as Surface Protectant of Packaging Materials against Corcyra cephalonica Staint. in Stored Pearlmillet Pennisetum glaucum (Linn.) R. Br. emend Stuntz. Int.J.Curr.Microbiol.App.Sci. 8(10): 657-665. doi: https://doi.org/10.20546/ijcmas.2019.810.074 